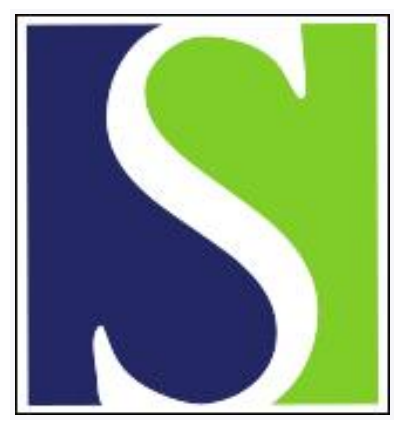

Scand J Work Environ Health 1996;22(5):387-391

https://doi.org/10.5271/sjweh.159

Issue date: Oct 1996

Hematopoietic and reproductive hazards of Korean electronic workers exposed to solvents containing 2-bromopropane

by Kim Y, Jung K, Hwang T, Jung G, Kim H, Park J, Kim J, Park J, Park D, Park S, Choi K, Moon Y

Key terms: amenorrhea; anemia; azoospermia; dibromochloropropane; leukopenia; oligospermia; ovarian failure; thrombocytopenia

This article in PubMed: www.ncbi.nlm.nih.gov/pubmed/8923614 


\title{
Hematopoietic and reproductive hazards of Korean electronic workers exposed to solvents containing 2-bromopropane
}

\author{
by Yangho Kim, MD, ${ }^{1}$ Kapyull Jung, MD, ${ }^{2}$ Taiyoung Hwang, MD, ${ }^{2}$ Gyungwoo Jung, MD, ${ }^{2}$ \\ Hyojin Kim, MD, ${ }^{2}$ Joosung Park, MD, ${ }^{2}$ Joonyoun Kim, MD, ${ }^{2}$ Jungsun Park, MD, ${ }^{1}$ \\ Dongwook Park, PhD, ${ }^{\prime}$ Seunghyun Park, BSC, ${ }^{1}$ Kyeongsook Choi, MD, ${ }^{1}$ Younghahn Moon, MD ${ }^{1}$
}

\begin{abstract}
Kim Y, Jung K, Hwang T, Jung G, Kim H, Park J, Kim J, Park J, Park D, Park S, Choi K, Moon Y. Hematopoietic and reproductive hazards of Korean electronic workers exposed to solvents containing 2-bromopropane. Scand $J$ Work Environ Health 1996;22:387-91.

Objectives The purpose of this study was to describe hematopoietic and reproductive hazards of Korean electronic workers exposed to solvents containing 2-bromopropane.

Methods Detailed medical and occupational histories were taken and thorough physical examinations with clinical laboratory tests were done for 33 workers ( 8 men and 25 women). Previous and present exposure was investigated in detail by industrial hygienists.

Results Of the 25 female workers, 16 were shown to have secondary amenorrhea with high follicle-stimulating hormone levels, normal prolactin levels, and hot flashes. A total of eight workers with amenorrhea concurrently showed findings of pancytopenia. Among eight male workers, two showed azoospermia and another four showed some degree of oligospermia (normal $>20$ million $\cdot \mathrm{ml}^{-1}$ ) or reduced sperm motility (normal $>50 \%$ ). The bone marrow effects and the testis or ovarian failure was shown to be the main health hazards in this workplace. Except for the cleaning solution containing 97.4\% 2-bromopropane, no other known physical or chemical agents could be identified as responsible for the gonadal and bone marrow effects, including ionizing radiation, lead, ethylene glycol ether and its acetates, benzene, and dibromochloropropane.

Conclusions No previous studies have reported human toxicity for 2-bromopropane, but the results of this study lead to the tentative conclusion that the causal agent for the gonadal and bone marrow effects among the workers might be 2-bromopropane.
\end{abstract}

Key terms amenorrhea, anemia, azoospermia, dibromochloropropane, leukopenia, oligospermia, ovarian failure, thrombocytopenia.

For a small group of workers performing the process of very small-sized tactile switch assembling in an electronics factory in South Korea, a finding of hematopoietic and reproductive effects has been reported. Preliminary results of an industrial hygiene investigation revealed that a solvent containing 2-bromopropane was the most probable cause of the health hazard. Because this solvent was known to be internationally traded by a Japanese manufacturer as an alternative to freon, which is known to destroy the stratospheric ozone layer, we are urgently reporting the case series to describe hematopoietic and reproductive hazards of the victims. To our knowledge, this is the first report related to the occupational hazards of solvents containing 2-bromopropane.

\section{Subjects and methods}

An occupational health manager in an electronics factory in South Korea reported a cluster of cases of secondary amenorrhea among workers in the tactile switch assembly section to the Republic of Korea Department of Labor. The physicians and industrial hygienists of the National Institute of Occupational Health, Korea Industrial Safety Corporation (KISCO), responded to the request and performed an emergency investigation. The investigation team identified 33 workers ( 8 men and 25 women) in the section who served as the study population.

Detailed medical and occupational histories, including the use of medication, were taken; thorough physical

1 Industrial Health Research Institute, Korea Industrial Safety Corporation (KISCO), Kusan-Dong, Bupyeong-Ku, Incheon, South Korea.

2 Dong-A Medical Center, Dongdaesin-Dong, Seo-Ku, Pusan, South Korea.

Reprint requests to: Dr Yangho Kim, Industrial Health Research Institute, Korea Industrial Safety Corporation (KISCO), Kusan-Dong, Bupyeong-Ku, Incheon 403-120, South Korea. 
examinations were also done together with clinical laboratory tests. The laboratory tests were analyzed at a nearby teaching hospital, the Dong-A Medical Center, and comprised hematologic investigations such as common blood count, hemoglobin, and test for bleeding tendency (bleeding time, prothrombin time, and activated partial prothrombin time); hormonal studies such as FSH (follicle-stimulating hormone), LH (luteinizing hormone), prolactin, estradiol (measured for three women only), and testosterone; kidney and liver function tests; a thyroid function test; semen analysis; and other tests including radiographic studies (chest film), urinalysis, and electrocardiography (ECG).

\section{Exposure}

A detailed industrial hygiene investigation was done on current and previous work practices and control measures including ventilation.

The age range of the workers was $24-44$ years. For the female workers, the duration of exposure to the onset of amenorrhea was shown to be 4 to 16 months. The duration of exposure for the male workers was $16-19$ months.

The chemical composition of the cleaning agent used in the section was analyzed with a gas chromatograph with a mass selection detector (GC-MSD), (Hewlett Packard 5871 II, United States). No data were available regarding the air concentrations of the chemicals in the workplace or the biological monitoring of solvents. Soon after the reporting, the operation was stopped, and workers were no longer exposed. To estimate the level of exposure to solvents among the workers during normal workdays, we monitored the air concentration of various chemicals used in the section after setting up a simulated condition. A total of 14 area samples were collected to obtain general information on background exposure near each cleaning bath and some automatic assembling machines over $3 \mathrm{~h}$. Short-term exposure levels were monitored inside the hood of cleaning baths for $15 \mathrm{~min}$. Air samples were analyzed with a gas chromatograph (Hewlett Packard 5890 II, United States). The bulk and air samples were analyzed at the Industrial Health Research Institute of KISCO, designated as the reference laboratory by the Korean government. This reference laboratory has participated in the proficiency analytical testing program of the American Industrial Hygiene Association and has performed internal quality control programs.

The major component of the solvents used in the process was found to be 2-bromopropane (97.4\%) by GC-MSD analysis. Other components of the solvent were $n$-heptane $(0.33 \%)$, 1,2-dibromopropane $(0.2 \%)$, and 1,1,1-trichloroethane $(0.01 \%)$. The content of the air samples was 2 -bromopropane and $n$-heptane. The mean of the 2-bromopropane concentration in 14 area samples was 12.4 (SD 3.13, range 9.2-19.6) ppm. The shortterm exposure level, monitored inside the hood of the cleaning baths, was 4140.7 ppm (2-bromopropane), 29.8 ppm (n-heptane), and <1 ppm (1,1,1-trichloroethane). Neither benzene nor ethylene glycol ethers were detected in the bulk or air samples.

\section{Manufacturing process}

The whole process was done in a large room separated from the other processes. There were seven assembly lines, each with one cleaning bath and hood, and three or four automatic assembling machines. First, serially connected tactile switch parts were delivered to the cleaning bath and dipped in the cleaning solution for several seconds. The solution degreased the part and also filled the chinks between the resin and terminals with polytetrafluoroethylene, a component of the solution. This component prevents flux from infiltrating into the chinks between the resin and terminals of the part when lead soldering is done in a later process and makes the tactile switch function well. After passing through the cleaning bath, the parts were fed into the automatic assembling machine and assembled into a complete tactile switch. The same cleaning solution was used in all seven cleaning baths. The cleaning solution was changed from freon to the solution containing 2-bromopropane one and a half years ago. One or two female workers who manually treated troubles that occurred in the hood of the cleaning bath or assembling machines were located on each line. Male workers periodically resupplied the cleaning solution in the bath, controlled the concentrations of the solution, and checked the bath and assembling machines. All the workers did 12-h shifts.

\section{Results}

Table 1 shows the hematopoietic and reproductive hazards of 16 affected female workers. Of the 25 female workers in the section, 16 reported secondary amenorrhea for various periods ( $2-14$ months). In the clinical interviews and examinations they were found to have had normal menstruation up to this outbreak, and they had not used any special medications or the pill during their time on the job. The FSH levels of the 16 female workers were elevated (range 27.8-136.7 $\mathrm{mIU} \cdot \mathrm{ml}^{-1}$ ), and most of the women complained of hot flashes. The LH levels were also elevated for most of the female workers. The prolactin levels were, however, within the normal range. Progesterone withdrawal bleedings were not observed in any of the workers with amenorrhea. The 
estradiol levels of the three female workers were below the detection limit. A total of eight workers (cases 1-8) with amenorrhea showed concurrent findings of pancytopenia. The other women showed findings of mild anemia or mild leukopenia. Bone marrow biopsy was done for those with marked pancytopenia (cases 1 and 2). The biopsy findings showed marked hypoplastic marrow ( $15 \%$ and $25 \%$ cellularity, respectively). However, the results of the tests for bleeding tendency, kidney and liver function tests (except for case 22), thyroid function tests, chest radiographs, urinalyses, and ECG were found to be normal for the affected workers. Many workers in the section complained of nonspecific symptoms such as headache, dizziness, or weakness. The two workers with marked pancytopenia especially complained of easy bruisability.
Table 2 shows the reproductive hazards of the six affected male workers. Of the eight male workers in the section, two showed azoospermia and another four showed some degree of oligospermia (defined as sperm count less than 20 million $\cdot \mathrm{ml}^{-1}$ or reduced sperm motility defined as $<50 \%$ ). The male workers who were single or married with several children had not tried to have children, and none of them had especially complained of any problems with respect to fertility. The FSH levels were near the upper normal range, but the testosterone levels were within the normal range in the affected workers (table 2). Some male workers complained of nonspecific subjective symptoms such as headache or dizziness, but none complained of loss of libido. One worker with azoospermia (case 17) was also shown to have mild pancytopenia.

Table 1. Demographic, clinical and laboratory features of the female workers in the section. (FSH=follicle-stimulating hormone, $\mathrm{LH}=$ luteinizing hormone)

\begin{tabular}{|c|c|c|c|c|c|c|c|c|c|c|c|c|c|}
\hline Case & $\begin{array}{c}\text { Age } \\
\text { (years) }\end{array}$ & $\begin{array}{l}\text { Duration } \\
\text { of exposure } \\
\text { (months) }\end{array}$ & $\begin{array}{c}\text { Hemo- } \\
\text { globin } \\
\left(g \cdot d^{-1}\right)\end{array}$ & $\begin{array}{c}\text { Hema- } \\
\text { tocrit } \\
(\%)\end{array}$ & $\begin{array}{c}\text { Erythro- } \\
\text { cytes } \\
\left(10^{6} \text { cells }\right. \\
\left.\mu^{-1}\right)\end{array}$ & $\begin{array}{c}\text { Leuko- } \\
\text { cytes } \\
\text { (cells. } \\
\mu^{-1} \text { ) }\end{array}$ & $\begin{array}{c}\text { Platlet } \\
\left(10^{4} \text { cells }\right. \\
\left.\mu^{-1}\right)\end{array}$ & $\begin{array}{l}\text { Duration } \\
\text { of } \\
\text { amenor- } \\
\text { rhea } \\
\text { (months) }\end{array}$ & $\begin{array}{c}\text { FSH } \\
\text { level } \\
\left(\mathrm{mlU} \cdot \mathrm{ml}^{-1}\right)\end{array}$ & $\begin{array}{c}\mathrm{LH} \\
\text { level } \\
(\mathrm{ml} \cdot \mathrm{ml-1})\end{array}$ & $\begin{array}{c}\text { Estradiol } \\
\text { level } \\
\left(\mathrm{pg} \cdot \mathrm{ml}^{-1}\right)\end{array}$ & $\begin{array}{c}\text { Prolactin } \\
\text { level } \\
\left(\mathrm{ng} \cdot \mathrm{ml}^{-1}\right)\end{array}$ & $\begin{array}{c}\text { Hot } \\
\text { flashes }\end{array}$ \\
\hline 1 & 44 & 11 & 6.7 & 18.5 & 2.28 & 1910 & 1.5 & 7 & 118.6 & 12.9 & .. & 5.58 & + \\
\hline 2 & 20 & 7 & 8.7 & 26.2 & 2.57 & 1650 & 1.7 & 10 & 95.1 & 38.2 & 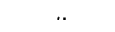 & 8.89 & + \\
\hline $3^{b}$ & 23 & 12 & 9.6 & 31.3 & 3.40 & 3030 & 6.5 & 6 & 136.7 & 41.7 & 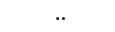 & 7.37 & - \\
\hline 4 & 41 & 8 & 11.2 & 31.8 & 3.34 & 3670 & 5.1 & 10 & 62.6 & 29.2 &. & 12.1 & + \\
\hline 5 & 20 & 11 & 11.5 & 33.2 & 3.54 & 2450 & 7.2 & 6 & 77.8 & 33.1 & .. & 9.22 & - \\
\hline 6 & 22 & 14 & 10.7 & 30.6 & 3.50 & 3850 & 9.6 & 2 & 97.3 & 39.1 & $<13.6$ & 5.53 & - \\
\hline 7 & 34 & 9 & 10.6 & 31.7 & 3.50 & 3020 & 11.9 & 9 & 42.7 & 11.5 &.. & 4.93 & - \\
\hline 8 & 24 & 15 & 12.2 & 36.2 & 3.70 & 3310 & 10.9 & 3 & 80.0 & 42.7 & .. & 5.68 & + \\
\hline 9 & 20 & 11 & 12.7 & 38.1 & 4.20 & 3980 & 14 & 6 & 101.2 & 34.3 & .. & 7.50 & + \\
\hline 10 & 44 & 9 & 11.6 & 36.2 & 3.58 & 3750 & 13 & 10 & 42.9 & 18.0 & .. & 3.6 & + \\
\hline 11 & 22 & 13 & 13.7 & 41.2 & 4.46 & 3720 & 21.5 & 6 & 101.5 & 24.8 & .. & 11.7 & - \\
\hline 12 & 39 & 6 & 12.3 & 34.7 & 3.33 & 5370 & 18.5 & 14 & 93.9 & 11.3 & .. & 7.79 & + \\
\hline 13 & 21 & 4 & 12.3 & 36.5 & 3.92 & 5330 & 18 & 3 & 75.1 & 20.9 & .. & 5.51 & + \\
\hline 14 & 25 & 5 & 11.9 & 36.5 & 3.62 & 4890 & 13.6 & 12 & 27.8 & 48.7 & & 2.65 & + \\
\hline 15 & 20 & 7 & 11.5 & 33.7 & 3.67 & 5150 & 14.5 & 3 & 45.3 & 24.7 & $<13.6$ & 3.67 & - \\
\hline 16 & 26 & 16 & 12.3 & 36.5 & 4.13 & 5670 & 18 & 3 & 60.3 & 34.6 & $<13.6$ & 6.90 & + \\
\hline Refe & & & $12-16$ & $37-47$ & $4.2-5.4$ & $\begin{array}{c}4800- \\
10800\end{array}$ & $13-40$ & & $1.9-11.9^{c}$ & $\begin{array}{l}1.9- \\
11.9 c\end{array}$ & $30-120^{d}$ & $3.6-18.9$ & \\
\hline
\end{tabular}

a Duration of exposure from the onset of exposure.

- Combined iron deficiency anemia.

- At follicular phase.

d $0.11-0.44 \mathrm{nmol} \cdot \mathrm{I}^{-1}$, at early follicular phase.

Table 2. Demographic, clinical and laboratory features of the male workers in the section. (FSH $=$ follicle-stimulating hormone, $\mathrm{LH}=$ luteinizing hormone)

\begin{tabular}{|c|c|c|c|c|c|c|c|c|c|c|c|c|c|}
\hline Case & $\begin{array}{c}\text { Age } \\
\text { (years) }\end{array}$ & $\begin{array}{c}\text { Duration } \\
\text { of } \\
\text { exposure } \\
\text { (months) }^{\text {a }}\end{array}$ & $\begin{array}{l}\text { Hemo- } \\
\text { globin } \\
\left(\mathrm{g} \cdot \mathrm{dl}^{-1}\right)\end{array}$ & $\begin{array}{l}\text { Hema- } \\
\text { tocrit } \\
(\%)\end{array}$ & $\begin{array}{l}\text { Erythro- } \\
\text { cytes } \\
\text { (cells } \cdot \mu^{-1} \text { ) }\end{array}$ & $\begin{array}{c}\text { Leuko- } \\
\text { cytes } \\
\text { (cells. } \\
\mu^{-1} \text { ) }\end{array}$ & $\begin{array}{c}\text { Platlei } \\
\left(10^{4} \text { cells }\right. \\
\left.\mu^{-1}\right)\end{array}$ & $\begin{array}{c}\text { FSH } \\
\text { level } \\
\text { (mlU.m-1) }\end{array}$ & $\begin{array}{c}\text { LH } \\
\text { level } \\
\left(\mathrm{mlU} \cdot \mathrm{m}^{-1}\right)\end{array}$ & $\begin{array}{c}\text { Prolactin } \\
\text { level } \\
\left.\text { (ng } \mathrm{ml}^{-1}\right)\end{array}$ & $\begin{array}{c}\text { Sperm } \\
\text { count } \\
\left(10^{6} \cdot \mathrm{ml}^{-1}\right)\end{array}$ & $\begin{array}{l}\text { Sperm } \\
\text { motility } \\
(\%)\end{array}$ & $\begin{array}{c}\text { Testos- } \\
\text { terone } \\
\text { level } \\
\left(\mathrm{ng} \cdot \mathrm{ml}^{-1}\right)\end{array}$ \\
\hline $\begin{array}{l}17 \\
18^{b} \\
19 \\
20 \\
21 \\
22^{c}\end{array}$ & $\begin{array}{l}28 \\
37 \\
25 \\
32 \\
24 \\
36\end{array}$ & $\begin{array}{l}19 \\
19 \\
19 \\
17 \\
16 \\
19\end{array}$ & $\begin{array}{l}11 \\
13.8 \\
14.8 \\
15 \\
13.3 \\
14\end{array}$ & $\begin{array}{l}31.6 \\
42.3 \\
42 \\
43.3 \\
38.5 \\
42.1\end{array}$ & $\begin{array}{l}3.53 \\
4.06 \\
4.65 \\
4.48 \\
4.15 \\
4.66\end{array}$ & $\begin{array}{r}4680 \\
10900 \\
4680 \\
7150 \\
7550 \\
4340\end{array}$ & $\begin{array}{r}6.8 \\
22.7 \\
18.9 \\
18.1 \\
16.1 \\
17.2\end{array}$ & $\begin{array}{l}18.1 \\
19.0 \\
16.8 \\
16.8 \\
13.5 \\
17.3\end{array}$ & $\begin{array}{l}8.73 \\
3.3 \\
3.78 \\
4.65 \\
4.29 \\
2.38\end{array}$ & $\begin{array}{c}6.64 \\
7.4 \\
30.7 \\
7.09 \\
8.9 \\
4.75\end{array}$ & $\begin{array}{l}0 \\
0 \\
1.9 \\
5.3 \\
7.7 \\
19\end{array}$ & $\begin{array}{l}0 \\
0 \\
25 \\
63.6 \\
31.3 \\
49\end{array}$ & $\begin{array}{r}4.74 \\
2.99 \\
11.68 \\
7.11 \\
7.17 \\
3.2\end{array}$ \\
\hline efe & & & $14-18$ & -52 & $4.7-6.1$ & $\begin{array}{r}4800 \\
10800\end{array}$ & $13-40$ & $1.2-17.8$ & $1.4-11.1$ & $3.6-18.9$ & $>20$ & $>50$ & $2.7--10.0^{\circ}$ \\
\hline
\end{tabular}

a Entire duration of exposure.

- Eosinophilia $9.4 \%$.

c Aspartate aminotransferase $/$ alanine aminotransferase $=39 / 79$ (reference value $\left.=10-\left.35 \mathrm{IU} \cdot\right|^{-1}\right)$.

d $9-\left.35 \mathrm{nmol} \cdot\right|^{-1}$ 


\section{Discussion}

Ovarian failure is defined as a failure of ovarian estrogen production in the setting of hypergonadotropism. The diagnosis is confirmed by elevated gonadotropin levels, particularly FSH levels greater than $40 \mathrm{mIU} \cdot \mathrm{ml}^{-1}$, and incipient ovarian failure is diagnosed with FSH levels greater than $20 \mathrm{mIU} \cdot \mathrm{ml}^{-1}(1,2)$. Secondary amenorrhea with high FSH levels, normal prolactin levels, and symptoms suggestive of menopause (such as hot flashes) were not due to strenuous exercise or environmental stress, but to ovarian failure $(1,2)$. The low estradiol levels of three female workers were compatible with ovarian failure, for which no progesterone withdrawal bleeding could be observed. For the six male workers with azoospermia or oligospermia, the FSH levels were near the upper normal range, but the testosterone levels were within the normal range. Hence the target tissue of the health hazard is the germ cells, but not the Leydig cells of the testis. From bone marrow findings compatible with aplastic anemia (3), the hematologic findings of these workers were due to bone marrow depression. We conclude that the bone marrow effects and the testis or ovarian failure were the main health hazards in this workplace. It is notable that these organs are composed of rapidly proliferating cells such as hematopoietic cells and germ cells. This finding suggests the existence of a common causative agent which inhibits normal cell divisions in the human body.

Although previous and present exposure has been investigated in detail by the industrial hygienists, except for the cleaning solution containing 97.4\% 2-bromopropane, no previously known physical or chemical agents could be identified to be responsible for the gonadal and bone marrow effects, including ionizing radiation (4), lead (5), formaldehyde (6), ethylene glycol ether and its acetates (7), benzene (8), dinitrobenzene (9), and dibromochloropropane (DBCP) $(10,11)$.

The responsible agent for the poisoning is likely to be one of the chemicals in the solution, most likely 2-bromopropane. This relatively new chemical was recently introduced as a substitute for freon, which is known to destroy the stratospheric ozone layer. Unfortunately, however, toxicologic data are not yet available for this chemical (12). No occupational standards have been instituted. Other minor components included in the solution were $n$-heptane and polytetrafluoroethylene. $n$-Heptane, detected in trace amounts in the air, was less likely to be the causal agent of the hematopoietic or reproductive health effects, and polytetrafluoroethylene is known to be stable at room temperature, as in this process.

It is notable that 2-bromopropane has a chemical structure similar to that of $\operatorname{DBCP}(13,14)$, which has been reported to cause male infertility $(10,11)$. Male workers with DBCP-induced oligospermia or azoosper- mia had increased levels of FSH, and normal levels of testosterone $(15,16)$. In animals, testicular damage by DBCP is accompanied by hematopoietic toxicity such as anemia, leukopenia, or bone marrow hypoplasia $(11,17)$. The abolition of estrus cycles was also observed in female animals (11). Because of these similarities of toxicology data for DBCP to our results of 2-bromopropane, we speculate that 2-bromopropane, as an alkylating agent, might inhibit rapidly proliferating cells such as hematopoietic cells or germ cells of the testis or ovary.

These chemicals, which were imported for the cleaning solution from Japan through legitimate foreign trade, have not been regulated in any country, and no attention had been paid to their monitoring before the outbreak in this factory. The evaluation of the local and general ventilation systems of the workplace revealed that some of the local ventilation systems were inadequate, and part of the vented air was recirculated into the room. The workers were likely to be exposed to a background level of 9.2-19.6 ppm. But, occasionally, the workers might be exposed to 2-bromopropane in concentrations as high as several thousand parts per million for a short period during the manipulation of the cleaning baths. The workers, not being informed of any potential hazard from these chemicals, did not wear any personal protection equipment, and sometimes they showed poor personal hygiene such as hand dipping practices. It is known that 2 -bromopropane is very volatile and that it can be absorbed through the skin (12). These observations indicate that the exposure of these workers could have been significantly high.

No previous studies have reported 2-bromopropane to be toxic to humans, but these results lead us to the tentative conclusion that the causal agent for the gonadal and bone marrow effects among these workers might be 2-bromopropane. To confirm this hypothesis, we have started a thorough epidemiologic study including sporadically exposed workers throughout the factory. Toxicologic studies of 2-bromopropane on animals are also in progress. Furthermore, we are planning to follow the workers to confirm the causal agents of the health hazards, as well as to determine the prognosis.

\section{References}

1. Barbieri RL, Ryan KJ. The menstrual cycle. In: Ryan KJ, Berkowitz RS, Barbieri RL, editors. Kistner's gynecology: principles and practice. 6th edition. St Louis (MO): Mosby, 1995:11-49.

2. Rein MS, Schiff I. Evaluation of the infertile couple. In: Ryan KJ, Berkowitz RS, Barbieri RL, editors. Kistner's gynecology: principles and practice. 6th edition. St Louis (MO): Mosby, 1995:278-304.

3. Rappeport JM, Nathan DG. Acquired aplastic anemia: pathophysiology and treatment. Adv Intern Med 1982;27:547. 
4. Henshaw PS. Further problems in X-ray protection II Irradiation injury and the tolerance dose. Radiology 1945;44:56980.

5. Keogh JP. Lead. In: Sullivan J, Krieger G, editors. Hazardous materials toxicology, clinical principles of environmental health. Baltimore (MD): William and Wilkins, 1992:834- 44.

6. Barlow SM, Sullivan FM. Reproductive hazards of industrial chemicals. London: Academic Press, 1982:334 45.

7. Kalf GF, Post GB, Snyder R. Solvent toxicology: recent advances in the toxicology of benzene, the glycol ethers, and carbon tetrachloride. Annu Rev Pharmacol Toxicol 1987;27: 399-427.

8. Barlow SM, Sullivan FM. Reproductive hazards of industrial chemicals. London: Academic Press, 1982:83-103.

9. Anonymous. Dinitrobenzene. J Appl Toxicol 1989;9:199 202.

10. Giwerman A, Carlsen E, Keiding N, Skakkebaek NE. Evidence for increasing incidence of abnormalities of the human testis: a review. Environ Health Perspect 1993;101 suppl 2:65-71.

11. Wills JH. Dibromochloropropane. In: Parmeggiani L, editor. Encyclopedia of occupational health and safety. 3rd edition.
Geneva: International Labour Organization, 1983:621-3.

12. Lewis RJ. Sax's dangerous properties of industrial materials. New York (NY): Van Nostrand Reinhold, 1989.

13. Låg M, Søderlund EJ, Omichinski JG, Brunborg JA, Holme JE, Dahl SD, et al. Effect of bromine and chlorine positioning in the induction of renal and testicular toxicity by halogenated propanes. Chem Res Toxicol 1991;4:528-34.

14. Låg M, Omichinski JG, Dybing E, Nelson SD, Søderlund EJ. Mutagenic activity of halogenated propanes and propenes: effect of bromine and chlorine positioning. Chem Biol Interact 1994;93:73-84.

15. Barlow SM, Sullivan FM. Reproductive hazards of industrial chemicals. London: Academic Press, 1982:253-68.

16. Sandifer SH, Wilkins RT, Loadholt CB, Lane LG, Eldridge JC. Spermatogenesis in agricultural workers exposed to dibromochloropropane (DBCP). Bull Environ Toxicol 1979;23: 703-10.

17. Saegusa J, Radiomimetic toxicity of 1,2-dibromo-3-chloropropane (DBCP). Ind Health 1986;24:1-14.

Received for publication: 25 March 1996 